\title{
THE ASSIGNMENT OF POWERS IN AN OPEN-ENDED EUROPEAN UNION
}

\author{
PIERRE SALMON \\ CESIFO WORKING PAPER No. 993 \\ CATEGORY 2: PuBlic CHOICE \\ JULY 2003
}

PRESENTED At CESifo CONFERENCE “A CONSTITUTION For THE EU”, FEBRUARY 2003

An electronic version of the paper may be downloaded

- from the SSRN website:

- from the CESifo website:

http://ssrn.com/abstract $=432901$

www.CESifo.de 


\title{
THE ASSIGNMENT OF POWERS IN AN OPEN-ENDED EUROPEAN UNION
}

\begin{abstract}
A major characteristic of the European Union is its transitional or evolving nature, in particular with regard to the assignment of powers between the two main levels of government. More precisely, under current constitutional arrangements, this evolving nature takes the form of an integration process which tends to be monotonous, that is, which can only with great difficulty be reversed. The paper is mainly devoted to the explanation of how this comes about and what effects this has on other features of the process. As a concluding remark, however, it suggests that an additional criterion for judging -- or an additional indicator for reading -- proposed constitutional reforms can be derived from the analysis. This criterion or indicator should be of some value independently of the position adopted with regard to European integration.
\end{abstract}

JEL Code: D72, F02, H77.

Keywords: european integration, european union, constitution, gradualism, transition.

\author{
Pierre Salmon \\ Université de Bourgogne \\ LATEC-CNRS \\ 2 boulevard Gabriel \\ 2100 Dijon \\ France \\ pierresalmon@compuserve.com
}

I am very grateful for the comments made on earlier versions of this paper by participants in the CESifo Conference "A constitution for the Europe Union" (especially, without implicating him, by my discussant, Stefan Voigt) as well as for the very useful suggestions included in two referee reports. 


\section{Introduction}

A major characteristic of the European Union (EU) is its evolving or transitional nature. This can be observed along at least three dimensions: in the way European institutions make decisions, in the size of the membership, and in the role played by the EU institutions within the overall governmental system of the part of Europe they cover. To the public, the last dimension is certainly the main one. EU institutions have progressively become central in an increased number of policy domains. In addition to international trade and agriculture, they have acquired a dominant influence over regulation, competition, and money. Other domains, such as internal security and immigration, may follow in the near future. Growth in the role and importance of Brussels (understood broadly so as to include Frankfort, Luxembourg and Strasbourg) is certainly the main perceived factor underlying the widespread perception that European integration is an ongoing process rather than a state, or the EU under construction rather than merely incomplete or unachieved.

Of course, if we turn to the question "transition to - or construction of - what?" things become more controversial. There is no agreed or even, perhaps, lucidly firm answer to that question. The EU may well become a sovereign state - and, if so, of a federal type - but it may also stabilise as some completely unprecedented (e.g., "post-national") form of political organisation. Many interrelated things or events can deviate the process in the one or the other direction, or, for that matter, directions currently unforeseen, such as collapse. In the language of modern theory, European integration, like some other institutional transformations or transitions of comparable magnitude, is subject to strong "aggregate uncertainty" (Roland, 2000). This, together with the absence of consensus on ultimate objectives, gives its evolving or evolutionary nature the specific characteristic of being very open-ended.

To what extent is the apparently ambitious idea of "a constitution for Europe" compatible with the perspective just recalled? Much depends on what is expected from that "constitution" - on the extent in particular to which it is seen as qualitatively different from the constitutional or quasi-constitutional rules that already govern EU institutions. In the next section, I will consider some of these expectations and argue that the ideas of the transitional and open-ended nature of the EU, on the one hand, and of "a constitution for Europe" to be agreed on in an explicit way, on the other hand, are neither contradictory nor immediately harmonious or consonant.

A way to make them work together is to focus on the aspects of constitutional or quasiconstitutional provisions that are responsible, currently or in the future, for shaping or constraining the open-ended evolution or transition. If the question is what change in the 
constitutional set-up may be brought about by an explicit constitution for the EU, the particular perspective stressed above suggests that we should pay some attention to the question of how any contemplated constitutional changes (say, an increase in the role of the European Parliament, or of majority-voting in the Council of Ministers) might affect the said shaping or constraining. This essay does not directly address that question but it purports to contribute to it in a preparatory way by analysing some important consequences of present arrangements on the shape of the integration process. The most crucial consequence, probably, is monotonocity or irreversibility: the present set-up makes the integration process run in a monotonous direction - allowing it, or often causing it, to stall, but only with great difficulty to be reversed.

The elements of the present constitution that produce that result are considered, under somewhat extreme assumptions, in Section 3, which shows the crucial importance of reversals. Section 4, focussed on position-trading, offers a more balanced or realistic view of constitutional constraints on reversals. It is argued in that section that, even under these more realistic assumptions, the existing constitutional arrangements do make reversals very difficult, and in that sense favour the status quo. By favouring the status quo, however, they also constrain the possibility of moving ahead, as analysed in section 5 . The integration process thus appears as an instance of the gradualist approach to large changes or transitions, an emerging theoretical domain whose importance is stressed and excellently illustrated in Roland (2000). But it is a very particular form of gradualism, as argued in section $6 .{ }^{1}$

Our analysis does not reflect personal preferences with regard to the pace of integration or lead to a particular normative or prescriptive position with regard to constitution-making at the EU level. As explained in the concluding section, this does not mean, however, that it is devoid of any operational significance. The analysis suggests a relatively precise criterion - or angle, indicator, perspective, dimension, etc. - to be selected, together with other considerations, and whatever one's preferences or opinions about integration, for the purpose of judging or, simply, reading proposed constitutional or quasi-constitutional innovations.

\section{Constitution-making and the evolving nature of the EU}

What is expected from the present and forthcoming phases of constitutional activity? At the pro-European end of the spectrum of positions about European integration, many traditional

\footnotetext{
${ }^{1}$ Various sets of assumptions that may underlie the adoption of a gradualist approach to social transformations are analysed theoretically in Roland (2000) and the literature the book synthesises. None of these sets fits very
} 
federalists think or hope that such phases signal that the time has come for the constitutional creation of a federal state. Federal systems are compatible with many kinds of arrangements, in particular a high degree of decentralisation, and the experience of existing decentralised federations is important when thinking about the EU (Kirchgässner and Pommerehne, 1996; Schneider, 1996; McKay, 2000; Salmon, 2002a). Also, as experience shows, the degree of centralisation typically evolves or fluctuates quite a bit in the course of time (Breton, 1996; Winer, 2000). ${ }^{2}$ Thus a federal constitution for Europe would certainly allow some kind of subsequent evolution. Still, this would take place within the limits of the defining characteristics of federal states, and this requirement is not innocuous. Two features of federations may prove particularly constraining. Even if very decentralised, the new federation would become a state. It seems difficult that such characteristic does not imply acting in a unitary way in domains such as defence and foreign affairs. Even more significantly perhaps, by the way of their participation in nation-wide elections and referenda, voters making up a majority of the population of the federation would be entitled to impose their views unilaterally against unwilling minorities in some important areas (say, taxation) and the minorities would have to acquiesce. As many federalists are well aware, given the present array of opinions in Europe a constitutional outcome of that kind is plausible only under an increased fragmentation of the EU membership, with the United Kingdom and some other member countries keeping out of federal ties for an undetermined period.

Now, fragmentation may be interpreted in such a way that it provides a second means (the first, mentioned above, being evolution within the limits of federalism) to reconcile the immediate establishment of a federal state with the evolutionary and open-ended nature of the European Union. For that purpose, a new constitution allowing deeper integration among a subset of countries could be interpreted as a way to deal with aggregate uncertainty, along a line similar (but not identical) to that suggested by Dewatripont et al. (1995). ${ }^{3}$ Federal arrangements would be tried by some and, if successful, others could join (or secede completely). It seems natural also (although deceptively so, as we shall see) that if the arrangements were deemed unsuccessful, a reversal could take place with a return to something like the status quo, entailing restored homogeneity. One must admit, however, that joining a federation or seceding from it are moves that suggest discontinuity rather than

well with the reasoning developed in this essay. However, no serious attempt can be made here to make explicit formally the theoretical underpinnings of that reasoning.

${ }^{2}$ All constitutions, also of unitary states, do evolve substantially in the course of time, for that matter. See Voigt (1999) for an analysis stressing the distinction between explicit and implicit constitutional change.

${ }^{3}$ See also Roland (2000, p. 37). 
gradualism. Also, giving a crucial role to the possibility of reversals seems quite foreign, as we will see, to the particular form that evolution takes in the case of the EU. For these reasons as well for others familiar to the historians of ideas about European integration, the evolutionist and the federalist perspectives are mutually compatible only to some point.

Situated on the other side of the spectrum, a second view is that of the relatively moderate Euro-sceptics who see in a constitution for Europe above all a way to block further integration, or even, perhaps, to obtain reversals in some areas. ${ }^{4}$ Many politicians and probably voters, not only in Britain, fall into that category. It seems a logical implication of that position that the constitutional and the evolutionary perspectives are essentially incompatible.

There are many economists and especially public choice economists whose writings make them seem close to euro-scepticism. In reality their position is generally different. It can be broken up into three views. First, they do not mind, or even they favour the process of integration accelerating in non-economic areas. In this, their position is not so far from that of the federalists. Second, they fully support the integration of markets, including the elimination of all impediments to trade and distortions of competition. Third, they would like the constitution to block centralising tendencies with regard to public finance and to economic and social policies other than those required for the implementation of the single market. This three-pronged position leads to a view of "a constitution for Europe" which makes it also largely incompatible with the transition interpretation of the EU. According to these economists' views, the main responsibility in domains such as foreign affairs, defence, and market integration could or should be assigned to the EU level. ${ }^{5}$ The trend toward an everincreased involvement of the EU level with the other policies, and its consequences with regard to finance and personnel, should be suppressed. This tends to give the recommendations a connotation of static equilibrium that renders them, if not incompatible, at least dissonant with that attached to institutional evolution.

In the middle (to speak loosely), whatever their own preferences, most actors and commentators expect a constitution for Europe to embody a compromise that will remain valid for some limited period of time, and will change a little but not radically the hybrid

\footnotetext{
${ }^{4}$ In the form of the side-payments and compensations that may prove necessary to reach the unanimity required for the adoption of new constitutional provisions.

${ }^{5}$ Economists are often influenced here by the theory of fiscal federalism, even though Guido Tabellini (2002) for instance insists that income distribution should not be transferred to the EU level. But an element of dissonance with evolutionary views may remain in approaches to European integration that are in principle open to such views and based on economic conceptions of federalism other than fiscal federalism (see, e.g., Breton, 1996; Breton and Ursprung, 2002; Salmon, 2003).
} 
nature of the EU. This view is quite realistic. More importantly for our purpose, it implies no denial of the evolutionary nature of the EU. The future constitution, if it comes into existence, is widely perceived as one step, important perhaps but not final. The other feature, openendedness, is another matter, however. Analyses fully conscious of the evolving and transitional character of the institutional set-up suggest nonetheless relatively precise or detailed types of constitutional arrangements. This is a perfectly natural and even fruitful attitude, especially in the context of ongoing constitutional debates. However, inasmuch as it leads to suggestions that do constrain or shape future solutions in an identified way, it does signal some departure from perspectives that have the characteristic of putting openendedness at the centre of stage. ${ }^{6}$ Given the limited objectives which, as noted, we set ourselves in this essay, the fact that we can to stick to that characteristic is not surprising. Hopefully, as noted also, the ensuing focus on present arrangements will be of some use more generally.

\section{The constitutional entrenchment of a goal-oriented evolution}

How do the current arrangements support the evolutionary nature of the EU? In this section, I assume that the issues are dealt with separately, without any attempt to link them for the purpose of bargaining. The three main ingredients of entrenchment are the definition of the goal or European integration as "ever closer union", the acquis communautaire principle, and unanimous decision-making in the Councils.

\subsection{The objective of an ever closer union}

All the member states have solemnly pledged to construct Europe. In the preamble of the Treaty of Rome, they express this commitment by asserting that they are "determined to lay the foundations of an ever closer union among the peoples of Europe." Thirty-six years later, in the preamble of the Treaty of Maastricht, the member states, including this time the United Kingdom, declare themselves to be "resolved to continue the process of creating an ever closer union among the peoples of Europe". The fact that this is immediately followed by the phrase "in which decisions are taken as closely as possible to the citizen in accordance with the principle of subsidiarity" is a welcome but minor qualification.

Different interpretations of this commitment have been proposed. One of them reduces it to little more than an obligation to support exchanges of ideas or persons across Europe. It

\footnotetext{
${ }^{6}$ Schneider (1996) and Berglöf (2003) are particularly interesting illustrations of this kind of work made by economists.
} 
can also be claimed that, since ideas, circumstances and majorities change in the course of time, government commitments such as this one will be typically weak (even if ratified in the name of the people). All this may be true but it remains that those who pretend to adopt a diminishing interpretation seem nonetheless very upset by the formulation used in the treaties and fight for its elimination from the future documents. This suggests that the minimalist interpretation lacks empirical support. The more generally agreed view is that, by the pledge to foster an ever closer union, the member states have committed to reinforce over the years the decision-making capacity of the European institutions. ${ }^{7}$

The centralising tendencies of the Commission, of the European Court of Justice and of the European Parliament have been noted by a number of authors, typically critical of the phenomenon observed (Vaubel, 1994). It seems difficult to deny the existence of these tendencies, nor that they are generated by imperialistic motivations typical of most organisations. However, given their commitment to pursue the project of constructing Europe, and the indirect way they thought this was to be done (I turn to that below), the creators or shapers of the European institutions necessarily had to entrust these institutions a major role toward the realization of the project. As a rule, thus, the centralising tendencies do not reflect an unwanted and unforeseen phenomenon of bureaucratic drift, or consequences of institutional decisions made for completely different purposes. More plausibly, they constitute an instrument designed or contrived to serve member states' common project (Salmon, $2002 \mathrm{~b}) .^{8}$ Even if, as seems clear, some governments would have preferred otherwise, that is, no centralising tendency to operate, the logic of their acquiescence to the project undermined their capacity to bring about the emergence of alternative structures generating no such tendency. This brings us to the second ingredient mentioned above.

\subsection{Acquis communautaire}

\footnotetext{
${ }^{7}$ As The Economist (2000) writes in a text entitled "Our constitution for Europe": "What needs to be fixed is...its constitutional underpinnings. First and foremost this means renouncing the guiding concept of "ever closer union", an idea enshrined in the Union's pseudo-constitution. Ever closer union, taken seriously, is a commitment to permanent constitutional revision - and Europe's leaders do take it seriously. Earlier agreements oblige them to seek further integration, they often point out. End of discussion. It is too late now, they say, to start asking where or whether integration should stop. Actually, it is not too late - except in the sense that the answer is already long overdue. Europe's leaders are right about what the existing treaties say. Therefore, plainly, those agreements must be changed."

8 This interpretation is fully compatible with the assumption of aggregate uncertainty mentioned earlier. Predicting that a bureau put at the centre of the system will try to expand its activities and influence in a direction related to the basic missions it was created for initially is the kind of achievement that can be a ascribed to moderately competent politicians even in a world of high aggregate uncertainty. Compare footnote 15 below.
} 
To borrow Knud Erik Jørgensen the title of his very interesting article (1999), the acquis communautaire principle is "a cornerstone of the European edifice". It refers to all the obligations accumulated since the predecessors of the EU - the European Community, of course, but also in some respects the European Coal and Steal Community of the early 1950s. There are two interpretations of the way in which the acquis operates. The less extensive one is related to the accession of new members. Applicant countries must accept to fulfil all the obligations constituting the acquis communautaire. This is non-negotiable. A delay for implementing some obligations is usually conceded but besides that there are only minor exceptions to the principle.

The acquis communautaire principle, endowed with a more extensive interpretation, is now endorsed by the Treaties, notably those of Maastricht and Amsterdam. The formulation implies that it is an objective of the EU to integrally maintain the acquis communautaire. ${ }^{9} \mathrm{I}$ do not think that this is an enforceable commitment and thus I stick to the less extensive status, related to the accession of new members, which is enough for my purpose. As many other constitutional rules of the EU, the acquis started in a somewhat inconspicuous fashion. It took the form of a contextual negotiation attitude adopted by the Commission and the six original members of the European Community to deal with the first candidacy of the United Kingdom - which would have much preferred to negotiate the rules and decisions it had to adapt to. That candidacy failed perhaps because of the condition. In 1969, on the initiative of the Commission, the principle was officially adopted by the six member countries as a condition imposed on the four applicants, Denmark, Ireland, Norway and, again, the United Kingdom. The condition remained in force in the following enlargements.

The accumulation of rules and decisions over several decades has led the size of the acquis communautaire to become really enormous. But particularly interesting is the way the domain it covers has been enlarged. The "political objective of the Treaties" was in from the beginning. The main doctrines of European Law (direct effect, supremacy, etc.), as framed by the European Court of Justice, was imposed (albeit not completely formally then) at the last minute before the final step of the first enlargement. Democratic principles and human rights were included for the negotiation with Greece, Portugal and Spain. Neutral countries such as Austria, Finland and Sweden had to accept the Common Foreign and Security Policy, including its (admittedly somewhat abstract) implications on defence, because they were part

\footnotetext{
${ }^{9}$ Some legal scholars claim that the acquis communautaire constitutes "an untouchable hard core, that is, an absolute substantial restriction implicitly imposed on any revision" (see Jørgensen, 1999, p. 12). The argumentation suggested in the text does not follow this, I think questionable, line.
} 
of the Treaty of the European Union already in force when they applied. The acquis communautaire imposed in the accession treaties of 2003 includes "the principle of open market economy with free competition." ${ }^{10}$

Each accession treaty is a kind of contract, which means that new members have the legal and moral obligation to take on board a number or explicit principles many of which started as much more informal and even tentative propositions and only later evolved to take their present form. In this process, what was initially meant to be a tentative constitutional interpretation may become the object of a formal recognition in an accession treaty and, as such, given an enhanced status by the European Court of Justice. Of course, once they are full members, the former applicants have the same rights as those enjoyed by older members. Consequently they can question or challenge what they want in existing arrangements - that is, in the acquis communautaire. The problem faced at this point, however, is the rule which would have to be used to decide a change.

\subsection{Unanimous decision-making in the European Councils}

The formal procedure to revise the constitution of the EU is unanimous agreement by the governments of the member countries followed by ratification in each country either by a vote in parliament or by a referendum. There are at least three reasons why we can neglect the ratification procedure and concentrate on the unanimous agreement between the governments. The main reason is that, even if the need to get ratification is certainly an important concern in the minds of negotiators, it is normally fully integrated, together with other concerns, in their position, attitude or strategy. The politicians involved here have been democratically chosen; they are supposed to represent the views of their constituents, and thus ratification is only a kind of confirmation that this supposition is correct. A ratification that fails reveals a mistake or is a small-probability event, in both cases not something very significant. Second, there are cases when ratification does take a particular importance but this introduces considerations which, although interesting, are not our main concern here. Bruce Ackerman (1997) argues that there is something like a founding act in the narrowly positive referendum which served in France for the ratification of the Maastricht Treaty. Negative referenda, that is voters refusing to approve a Treaty signed by their representatives, as in the case of Norway, Denmark, or Ireland, also make up intriguing subjects but their occurrence remains exceptional. Third, a very large number of decisions and rules can be changed only by

\footnotetext{
${ }^{10}$ On all these facts, and many more, see Jørgensen (1999).
} 
unanimous consent of the member countries even though the changes do not have to be ratified by the national parliaments or by the way or referendum. A large subset of these rules can be considered as constitutional or quasi-constitutional nonetheless.

In the next section we will qualify the stringency ascribed to the effects of the rule of unanimous voting. But, for the moment, let us assume that the rule is applied in a way which makes it practically stringent, and neglect also large constitutional changes brought about by the major treaties. This allows the following story: clause A corresponds to the preferences of the founding six member countries. It is imposed on the next three member countries on the occasion of the first enlargement, on three more members on the occasion of the second and third enlargements, and again on three new members on the occasion of the fourth enlargement. Let us stop here. The six founding members liked the clause and, we assume, still like it. The nine other members dislike it but have agreed to abide by it as long as it is not changed, thus in a weak sense have acquiesced to it (they did not dislike it to the point of giving up their application). In any case, they have to bear with it because changing would require also the consent of the six founding member countries, which, under the present assumptions, have no reason to award it. This story is not fully acceptable for reasons examined in the next section, but the path dependency it suggests is an important feature of reality. The organisation of the EU still reflects to some extent the arrangements agreed by the six in the fifties and is thus still influenced by the goals and beliefs that they shared.

\section{A more realistic view of constitutional constraints on reversal}

The conditions under which decisions are made in the EU, especially the decisions that have a constitutional or quasi-constitutional character, create a propitious ground for what Robert Cooter (2000) calls the "splicing of issues", that is, a mechanism that brings issues together so that positions over them can be exchanged. By analogy with vote-trading (also often called log-rolling), but to take into account a more general context, I will refer to that mechanism as "position-trading". The pervasiveness of recourse to that mechanism certainly qualifies the stringent effect of unanimity rule assumed in the previous section. But does it completely prevent constitutional rules to protect the acquis communautaire (and with it the "ever closer union" stipulation)? I think not, as I will try to show after some remarks on the said "issuesplitting" or "position-trading" mechanism.

\subsection{Bargaining under a rule of unanimity}


On the occasion of large multidimensional negotiations leading to new treaties, such as those which led to the Single European Act or to the Treaty of Maastricht, many issues are brought together, which allows a lot of side-payments, exchanges or compensations. As a consequence, the attachment of a country to a particular element of the status quo can be overcome in spite of the veto power that the rule of unanimity awards that country on that issue. For that to happen, the other participants in the negotiation must pay something. In a large negotiation most if not all countries, in spite of their veto power, will loose something on some issue, that is, will turn out to have made some concession.

Outside these large multidimensional negotiations, important decisions are also made that require unanimous consent of the member states. They are usually embedded in an ongoing process of bargaining among the states, which delivers an almost continuous flow of decisions of various importance. The forum used for that bargaining can be ordinary diplomatic channels, bilateral summit meetings among heads of state or government, the Council of Ministers, or the European Council. ${ }^{11}$ The government of the country chairing the two councils for the current semester usually serves as facilitator of bargains or compromise. To simplify, we can assume that bargaining takes place in the latter forum. Many issues are considered at each of the meetings of the European Council and these meetings take place twice a year. This means that decision-making is both multidimensional and/or sequential in time, each individual decision being made with due consideration of the others made or to be made contemporaneously, or situated in a slightly more distant past or future but always under a perspective of repeat business. This provides ample room for mutually beneficial reciprocation of positions over issues and characteristics of solutions. It must be noted that the items exchanged are not exclusively constitutional or quasi-constitutional characteristics but include also policies that address purely material concerns or, at the limit, includes also cash (under Margaret Thatcher, concessions about the refund to the United Kingdom was part of the compromise that led to the Single European Act).

There is a widespread claim that the outcome of decision-making under a rule of unanimity will typically have the character of a so-called "smallest common denominator."12 One implication of the foregoing discussion is that the idea cannot be correct. In fact, pure empirical observation should be enough to show that. New policies are often adopted that, in

\footnotetext{
${ }^{11}$ As is known, the latter is a regular "summit" among the heads of government and the president of the Commission. I do not pay sufficient attention in this essay to the no-doubt very important role played by the Commission, and in particular its president, in decision-making by unanimity among member states. I think, however, that taking that role explicitly into account would only reinforce the argument.
} 
themselves, are known by all observers to be disliked by many if not most of the member states who, nonetheless, unanimously give their assent to them. The elementary reasoning above explains how these policies are supported as elements of a larger position-trading compromise. What observation also tells us, however, is that sometimes unanimous decisionmaking does lead to the smallest common denominator (so to speak), in particular in its simplest form, which is inaction. The explanation is also usually straightforward: compared to what a result more to their taste would bring to members $\mathrm{X}$, the bribes they would have to pay to get that result are too high.

Bargaining and position-trading over several issues also take place under majorityvoting, as the literature on logrolling has analysed for a long time. This has two implications. One, which is well known, is that the median voter may not be decisive. Another is the blurring of the dividing line between issues that are decidable by majority-voting and issues that require unanimity. What will count now, whether or not the rule is unanimity or majorityvoting, is the intensity of the preferences of all the members on all the issues involved in the negotiation. The difference between the two rules remains important but in a more complex way than it would be in the absence of "position-trading." When member X is opposed to a proposal whereas a majority of other members are in favour of it, under the rule of unanimity, $\mathrm{X}$ would have to be compensated to accept the proposal and possibly the required compensation could be infinitely high. Under majority rule, if $\mathrm{X}$ obtains that the majority does not impose its adoption even though it could, $\mathrm{X}$ incurs a cost, subscribes a debt which will have to be repaid in the form of a concession in another area or on another occasion.

\subsection{What does this mean for the entrenchment of the acquis communautaire?}

The main idea that we should keep in mind is that a unanimous reform is always Pareto improving. The new situation, must be at least as good as the old one from the standpoint of each member. Whereas, under majority-voting, in the end the question is whether a majority considers the new package (including all the compensations and side payments) as better than the status quo, under unanimity it is each member who must judge the package better or in any case not worse than the status quo. ${ }^{13}$

The acquis communautaire is more or less what we mean here by status quo. Suppose that the main thing to be changed in that status quo is the elimination of the clause $\mathrm{A}$

\footnotetext{
${ }^{12}$ That is, for a given issue, a collective decision on that issue which satisfies each of the members on its own merits.

${ }^{13}$ See Buchanan (1975, chapter 5).
} 
mentioned in the previous section and that this clause is a constitutional characteristic, which has the dimension of a public good. Suppose that A provides utility to some members. To accept the elimination of $\mathrm{A}$, these members will have to be compensated and if their preferences for A are intense, the required compensation will be costly. Suppose in addition that the compensation can only marginally take the form of something akin to cash but must take above all the form of changes in some policies that also have the nature of public goods. Then finding a package that will satisfy the Pareto criterion referred to above will certainly not be easy. It will require much energy and creativity.

If it were available for that purpose, the power of initiative and leadership of the Commission would be most helpful, but the Commission is "a guardian of the treaties" and thus also, together with the European Court of Justice, a guardian of the acquis communautaire. More importantly, as noted, the logic of its situation (as contrived by the "founding fathers" of European integration) leads it to be biased in favour of integration. Thus the Commission is most likely to play against the elimination of $\mathrm{A}$, except if it also receives some sufficient compensation in the form of a pro-integration move in some other area.

Because of the assumption in this section that, under unanimity rule, it is possible to overcome a veto by the award of a compensation, the capacity of constitutional rules to maintain the status quo, and thus the acquis communautaire, is no more a matter of logic but an empirical question. Our discussion can only argue or suggest that the status quo will normally be quite resistant to attempts at changing it in the direction of a reversal, even assuming that a majority wishes such reversal. And the history of European integration readily confirms that significant reversals have been infrequent.

Does the argument, however, also apply to large scale negotiations of the kind that led to a new treaty such as the Treaty of the European Union (Maastricht) or the one that may be agreed on in 2004? I think that the argument does apply. The important point is that the existing treaty remains in force as long as a unanimous agreement on a new treaty has not been reached. This puts those who do not object too much to the existing treaty at an advantage in their negotiation with those who want to change it a lot - another way to say that the status quo is resistant. At this point, a question arises that could also constitute an objection to the thesis that existing constitutional constraints favour a goal-oriented evolution of the EU. If the constitutional rules favour the status-quo, how is it possible that they do not also hamper the evolution itself?

\section{Constitutional constraints on moving ahead}


The answer to the question raised at the end of the last section is straightforward: the constitutional rule of unanimity for the most important decisions (and some others as well) favours the status quo, and thus (at least with regard to direct effects) does slow down the process of integration. It does not block it completely or definitely though. Pace the unproven theory of the bicycle, once popular in circles close to Brussels, the process can stall for a relatively long period of time and then accelerate again. Its main property is thus monotonicity or irreversibility: either no movement at all or positive movement along one direction, no reversal. Hence the feeling of inexorability typically shared by Eurosceptics.

Let me again reason in two stages. Assume first that there is no bargaining over issues among the member states. Given the rule of unanimity, every step forward must be Paretoimproving on its own merits. This, however, does not preclude each member deciding on the basis of several criteria. Some members (the Pragmatists) have only one concern: the expected net effectiveness of the proposal with regard to meeting the concrete need(s) in discussion. Other members (the Ideologues) are concerned in addition about how the project fits into the overall evolution of the EU. Among the latter, some (the Eurosceptics or, perhaps less ambiguously, the Europhobes) consider as negative the fact that the proposal constitutes one step forward in the integration process whereas others (the Europhiles) consider this as positive.

Officially, nobody is europhobe (in the sense used here) in the Council of Ministers or the European Council. Let us assume for a moment that this is true. We need then consider only the Pragmatists and the Europhiles. For a project to be (here, unanimously) approved, a first condition is that it must thus be sufficiently attractive concretely to convince all the Pragmatists. A second condition is that, for each Europhile, the algebraic sum of what they perceive as the net concrete benefit of the project and what they see as its contribution to the integration process must be positive. For a Europhile, a project may have a negative net benefit in concrete terms, or more generally be judged ill-advised in the light of concerns independent of the integration issue, and nonetheless be acceptable because of its contribution to the construction of Europe. If we reintroduce the Europhobes, for each of them the progress that the project induces in the integration process, now valued negatively, must be compensated by a positive net concrete benefit of sufficient magnitude. Considering all the Ideologues together, what counts is the algebraic sum of this net concrete benefit and the benefit or cost derived from a step toward increased integration. For a project to be adopted, this sum must be positive for each member. 
Whether there are many or few integrative projects that meet this condition is an empirical matter. It is enough for the monotonicity property mentioned above that there are some. It may be the case that, over some periods of time, no such project will make it, so to say, and integration will stall - or seem to stall. ${ }^{14}$ Sometimes there will be a congestion of projects coming up at the same time, each apparently meeting the conditions. This may cause a reassessment of the net value put by some members on the projects (e.g., whereas each project, individually, would have been acceptable to the Europhobes, the sum may be unpalatable). Limited capacity of attention, deliberation or implementation will also impose a choice among acceptable projects.

Bargaining complicates somewhat the exposition without changing very much the substance. Necessary conditions can no more be singled out but the main ingredients in the overall result remain the same. To have a chance of being accepted, a proposal will now typically include various side-payments and compensations. To be unanimously approved each member will have to consider the proposal as an improvement on the status quo. In addition to the benefits and costs of the side-payments and compensations, the determinants of the final position of each member, however will be exactly those previously identified: the net benefit of the project with regard to the concrete need it constitutes a response of, and the positive or negative value assigned to its contribution to the process of integration. Certainly more proposals succeed than if there were no bargaining, but the overall result is qualitatively the same. Under the assumptions, integration progresses only when a project does pass the test, full stop.

To say a little more, empirical assumptions or speculations are needed. First, it is likely that the strength of europhily is stronger than that of europhobia. The ever-closer union objective is not only, so to say, wired in the instincts of the Commission, as noted, but it is also an important consideration among influential minorities (of citizens, elites, opinion, etc.), and possibly even majorities, in a large majority of the member countries. Supporters of integration will tend to welcome occasions to transfer new responsibilities to the Brussels level. This is reflected in the attitude of most member states. Opposition to integration is strong also in several countries but, at the level of government, it takes much more moderate forms. It is not clear, actually, that europhobia characterises the preferences of any of the governments currently in office among the member states. After all, as noted, the expression

\footnotetext{
${ }^{14}$ As observed by several authors, periods of apparent stagnation often hide inconspicuous decisions that turn out later to have been of great importance.
} 
"ever closer union" is included in the official documents agreed on by all the member countries.

That europhily is stronger than europhoby is conjectural, especially when meant to cover also the future. What is more certain is that both europhily or europhobia, at the level of each member country, are variables that are not independent of the size of the integrative step considered. For instance, the same member state's government which would give a positive value to a small step toward integration might judge negatively a larger step. And even if there is probably not much europhobia which is relevant in any of the member states' governments with regard to small steps, this would obviously change completely with regard to a step such as establishing a federation or a superstate. This remark raises the question of gradualism, to which I will return.

Recent history provides many illustrations of agreements between Europhiles and pragmatists or (perhaps) Europhobes. The most striking is the negotiation which led in 198586 to the Single European Act. That agreement launched the "1992" single market project and for that purpose increased the role of majority-voting within the Council of Ministers. Among the political parties or coalitions in office at the time, the unanimous agreement involved the French Socialists, led by François Mitterrand, and the British Conservatives, led by Margaret Thatcher. Even in retrospect, the motivations of these two politicians, who played a large role in the negotiation, are not perfectly clear. It seems safe, though, to say that the fact that the former was a devoted Europhile was decisive in the position he adopted, whereas both the budgetary rebate conceded to the UK and the freeing of markets played the main role in the assent given by the latter.

The commitments embodied in the Single European Act have turned out to have implications devastating for the feasibility of ideas that seemed at the time central to the doctrines of the two parties: still strong interventionism (industrial in particular), in the case of the French Socialists, and resolute hostility to centralisation at the EU level, in the case of the British Conservatives. ${ }^{15}$ This raises a question not discussed so far, which is that of the indirect consequences and spill-over effects of each step in the integration process. Before addressing it, let me mention a second illustration of assent to integrative steps by Pragmatists or Europhobes. During the negotiations that led to the Treaty of Maastricht - that is, a few years after the Single European Act and thus at a time when the centralising implications of

\footnotetext{
15 The implication is certainly not that either Thatcher or Mitterrand were irrational. First, they may have had priorities different from those exhibited by their parties (particularly likely in the case of Mitterrand). Second,
} 
the Act could escape the attention of no one - the British Conservative Government proposed that the powers of the European Court of Justice be substantially increased and in particular that it should be given the right to impose fines, a proposal which was duly integrated in the new Treaty.

\section{Constraints on the form of gradualism in the integration process}

Associated with the name of Jean Monnet, the method adopted by the member states to integrate Europe is based on the famous engrenage or spill-over principle. An integrative step decided in $\mathrm{t}+1$, raises problems that are typically solved or mitigated by agreeing in $\mathrm{t}+2$ on a new integrative step, which in turn will generate problems calling for a solution in $\mathrm{t}+3$, and so on. The underlying reason for that is the existence of complementarities (as noted, e.g., by Persson, Rolland and Tabellini, 1997). The argument developed in the foregoing sections purports to show that the constitutional set-up of the European Union favours this particular form of gradualism.

But this raises a number of questions. Why do not the governments choose an alternative process, akin to a big-bang strategy, consisting in tackling all the necessary transformations simultaneously and establishing, say, a federation? Why is not, in $\mathrm{t}+1$, all the sequence of integrative steps anticipated and taken into account when deciding the first step? In particular, why do not the members who are the most lukewarm vis-à-vis integration seem to act as if they were unaware of the distant implications of their decisions? One very strong argument for gradualism (central also to Roland, 2000) is the one used by Popper to justify piecemeal engineering: if the conjecture that inspires the reform proves wrong, that reform can be withdrawn, so to say, at not too high a cost. But is this compatible with the obstacles put by the present system to any kind of reversal?

\subsection{The choice of gradualism}

Many generally convergent explanations are available. The foregoing discussion, based in particular on the heterogeneity of preferences across the governments or the political majorities of the member countries, points to a type of explanation which is relatively straightforward, even though it remains to be elaborated. I have proposed elsewhere (Salmon, 1995) an interpretation of European integration which is much more unconventional, especially from the perspective of economics. I do not claim that this interpretation is the best 
one or the only one possible, but I summarise it because I happen subjectively to find it more plausible than several others. It purports to account not only for the characteristic of gradualism, but also for other features such as the process being round-about and looking like a conspiracy. It does not mention engrenage but is largely compatible with it. Contrary to some interpretations of European integration, the story I suggested in the 1995 essay does not rely on a distinction between elites and the rest of the population; contrary to most interpretations, it does not suppose that integration is typically useful or justified in economic terms.

Its basic assumption is that the ultimate aim of integration, shared by citizens, is to create strong and shock-resistant ties between the populations of the member countries. This has a psychological dimension, which cannot but be central. It implies a partial transfer in citizens (or in a sufficient number of citizens) of their attachment to - or identification with one type of collective, their nation states, toward another, the new European entity. ${ }^{16}$ This transfer is a gradual process that needs time. Citizens acquiesce to it in principle but, for various reasons, suffer some discomfort from the prospect, and thus prefer not to think too much about it. Elected office-holders serve the interests of citizens by, first, proceeding with integration and, second, giving it a form which makes it not too conspicuous. The 1995 essay includes two simple models. In both (with the exception of the variant summarised below), each individual transfer of powers is temporarily costly in terms of citizen utility and/or productive efficiency. ${ }^{17}$ It is consequently also costly, this time for office-holders, in electoral terms. But once citizens have adapted to the new division of powers, the cost evaporates, whereas the benefit, consisting of the transfer itself having strengthened the ties, remains. To decide each step, incumbent politicians, submitted to electoral competition, must enjoy some discretionary margin. The size of the margin constrains the size of the step - which explains that large steps are politically unfeasible as a rule.

A variant is based on an idea often expressed in the context of integration. In this variant, the process of market integration (simplifying a bit, so-called "negative' integration)

\footnotetext{
${ }^{16}$ There is an alternative hypothesis (more convenient in political terms) in which increased attachment to one collective implies no decrease in the attachment to another (see, for instance, Wallace, 2000). No transfer of attachments is needed then to generate ties. This alternative hypothesis underlies a large part of the discussion developed in the 1995 paper but is disregarded here.

17 In one of the models, citizen attachments are assumed to be factors of production in the sense that they contribute positively to the efficiency of policies. When two levels of governments are considered, attachments are level-specific in the short run. At any point in time, there is thus a constraining distribution of attachments between the two levels. In the longer run, attachments can be transferred from one level to the other. The productive efficiencies of policies is maximum when the allocation of resources or powers among the two levels match the distribution of attachments.
} 
generates in the people a gradual psychological process that allows, without this time any kind of temporary cost, a gradual transfer of powers (simplifying again, so-called "positive' inegration). Trying to move ahead with regard to positive integration quicker than what the psychological effects of negative integration allows has ill-effects in terms of productive efficiency, and therefore in electoral terms. ${ }^{18}$

\subsection{Apparently unforeseen implications.}

An objection to the reasoning followed in the preceding sections could consist in wondering why the implications of each decision, in particular when bringing about more integration, are not completely foreseen by all those who participate in that decision. If a sequence of steps were expected by all, what would be the difference between deciding on the first step and deciding on the whole sequence? A first response is very simple: members often do predict correctly many indirect consequences of their decisions and they do take into account these effects when they adopt a position. In particular, if a member does not value positively the overall sequence that follows, or may follow, from a proposed step in the absence of sufficient compensation on other matters, this will make that member adopt a negative position toward that step and thus, under the rule of unanimity, decide to block it. This constitutes another reason for many integrative projects not to be adopted by the member states, which does not change anything, qualitatively, to previous reasoning.

A second answer is based on the time horizon or discount rate of elected politicians. Illeffects that are expected correctly to follow from a decision albeit only several years hence may not weigh very much when balanced against reasons to take that decision that are responding to political pressure right now. One consideration is that the concerned politicians may not be in power anymore when the effects become perceptible. Another reason is that pressure groups of all kinds may also have a high discount rate. High discount rates of this nature are revealed, for instance, by the fact that a typical EU way to overcome deadlock is to adopt reforms on condition that their implementation be postponed.

The third answer is aggregate uncertainty, already mentioned. Interactions are extremely complex, equilibria multiple, external factors or shocks certainly of major importance but unpredictable, knowledge with regard to unprecedented historical transformations very fragile and limited, all of which meaning that the effects of macroscopic decisions are uncertain in a pretty radical sense of that word. Roland (2000) provides compelling theoretical and

\footnotetext{
${ }^{18}$ It is clear that the story applies better to the original six than to the members who joined later.
} 
empirical arguments supporting the point. The problem for our purpose is the major role he gives in that context to decision reversals.

\subsection{Gradualism without reversals}

As argued earlier, reversals of policy decisions or assignments of powers are not completely precluded by the present rules of the EU, nor are they rendered completely impossible by the way the EU works in practice. However, reversals certainly meet strong obstacles and are infrequent. When a problem arises and calls either for a decision reversing the integration process -- a "disintegration" (or "repatriation") solution -- or a new step in the sense of integration, the first alternative will rarely be discussed and in reality the choice will be between inaction, leaving the problem stand, or the integration-friendly solution.

This has several consequences. First, the bias may generate serious inefficiencies and difficulties in some circumstances. Second, the mechanism and its possible consequences is perfectly understood and anticipated by members. This awareness not only strengthens the reluctance to adopt policies of those who were already reluctant, but it may cool down the enthusiasm for moving ahead of all members. As a consequence, it will be harder for proposals to be adopted. Third, prudence will suggest limiting the size of each step forward -another reason for multi-step gradualism.

However, there are usually several solutions to each problem (each solution generating inn turns problems that have themselves several solutions), which means that, in the context of a given issue, excluding reversals will relatively seldom seem catastrophic. As noted, transitions in general are characterised by multiple equilibria, which opens up the possibility of very different paths - feasibility not to be confused with optimality, of course. This explains that all institutional arrangements are highly path-dependent and vary a lot across countries or systems. Making reversals very difficult has certainly an effect on the path borrowed by integration but this does not necessarily entail a serious weakness. Still, it does sometimes, as noted, and it certainly has a number of drawbacks. Hence the question of whether the rules should be improved. As indicated in the Introduction, there will be no attempt here to answer directly that question. The only suggestion is including an additional indicator in the set of indicators or criteria used to evaluate reform proposals.

\section{Concluding remarks}

On the occasion of discussions about the constitutional aspects of the EU, many ingredients of the present arrangements are seriously questioned. This is the case, in particular, of the 
principle of acquis communautaire, of the objective of "ever closer union", and of the procedure based on unanimous consent by the member states for changing the assignment of powers or for dealing with other constitutional or quasi-constitutional issues. Without trying to predict the outcome of negotiations or putting to the fore our personal preferences, what could be said about possible reforms?

The argument developed in the paper provides a kind of criterion, benchmark, indicator or standpoint for assessing the impact of proposed constitutional clauses: how will a proposal affect what I have called monotonocity (that is the monotonous character of the integration process) - or, in other, more dramatic words, its inexorability? As stressed earlier, the process of integration has often stalled or slowed down but it has seldom turned backwards, regressed. To generate monotonocity, the main factor is the difficulty of reversals. The easiness or difficulty of positive integrative steps is irrelevant. Thus, from the standpoint of monotonocity, the crucial point to examine in any proposal is its bearing on reversals, not on new steps.

Other criteria, more traditional or familiar than the one stressed in this essay, are likely to come to the mind more readily. Focussing on these other concerns is likely to prove more natural. As a consequence, the effects of new constitutional clauses on reversals and on monotonocity may well be overlooked. This is particularly likely to be associated with the desire to accelerate integration and to make it more democratic. These concerns explain that unanimous voting by member states is typically disliked per se as "intergovernmental", and that it seems a hindrance to the adoption of pro-integrative moves. Decision mechanisms are then typically proposed that reduce the reliance on unanimity for matters pertaining to the allocation of powers. They seem to be a way to accelerate integration. Among these decisionmaking mechanisms, in addition to qualified majority-voting by member states, one will find various means to increase the influence of the European Parliament or of the voters themselves. It is easy to forget that, at the same time as the transfer of new powers to the European institutions is facilitated by these mechanisms, inverse transfers, that is, reversals are also made easier to achieve, and thus that the monotonocity of the integration process may be undermined.

Many of the other criteria mentioned above fully deserve the attention they get. Moreover, as noted, monotonocity has a number of effects that will weigh heavily in one's judgement (slowing down integration, generating disincentives to experiment or simply to take risks, etc.). Thus, for instance, it would be wrong, therefore, to infer from our reasoning, as a general proposition, that partisans of integration should not support qualifications to - or 
departures from - unanimous voting by the member states. What one should only assert is the much more modest proposition that these "Europhiles" should keep the foregoing effect in mind. And, on the other side, this is also true, for that matter, of all those who support unanimous voting between member states because they think that this procedure constitutes a major hindrance to integration. As we have stressed, it does not. Inasmuch as Europhobes or Euroscepetics are above all worried by monotonocity, they also should pay more attention to the two sides of any increased reliance on majority-voting.

\section{References}

Ackerman, Bruce (1997), "The rise of world constitutionalism", Virginia Law Review, 83, pp. 771-97.

Berglöf, Erik et al. (2003), Built to last: a political architecture for Europe, London: CEPR. Breton, Albert (1996), Competitive Governments: An Economic Theory of Politics and Public Finance, Cambridge and New York: Cambridge University Press.

Breton, Albert and Heinrich W. Ursprung (2002), "Globalisation, competitive governments, and constitutional choice in Europe", Working Paper No. 657(2), January, CESifo, Munich.

Buchanan, James M. (1975), The Limits of Liberty: Between Anarchy and Leviathan, Chicago and London: The University of Chicago Press.

Cooter, Robert (2000), The Strategic Constitution, Princeton: Princeton University Press.

Dewatripont, Mathias et al. (1995), Flexible Integration: Towards a More Effective and Democratic Europe, London: CEPR.

Jørgensen, Knud Erik (1999), "The social construction of the acquis communautaire: a cornerstone of the European edifice", European Integration online Papers (EioP), 3(5) (http://eiop.or.at/texte/1999-005a.htm).

Kirchgässner, Gebbhard and Werner W. Pommerehne (1996), "Tax harmonization and tax competition in the European Union: lessons from Switzerland", Journal of Public Economics 60(3), pp. 351-371.

McKay, David (2000), "Policy legitimacy and institutional design: comparative lessons for the European Union", Journal of Common Market Studies, 28(1), pp. 25-54.

Persson, Torsten, Gérard Roland and Guido Tabellini (1997), "The theory of fiscal federalism: what does it mean for Europe?", in: H. Siebert (ed.), Quo Vadis Europe?, Tübingen: J.C.B. Mohr, pp. 23-41. 
Roland, Gérard (2000), Transition and Economics: Politics, Markets, and Firms, Cambridge (MA) and London: The MIT Press.

Salmon, Pierre (1995), "Nations conspiring against themselves: an interpretation of European integration", in: A. Breton, G. Galeotti, P. Salmon and R. Wintrobe (eds), Nationalism and Rationality, Cambridge and New York: Cambridge University Press, pp. 290-311.

Salmon, Pierre (2002a), "Decentralization and supranationality: the case of the European Union", in: E. Ahmad and V. Tanzi (eds), Managing Fiscal Decentralization, London and New York: Routledge, pp. 99-121.

Salmon, Pierre (2002b), "Accounting for centralisation in the European Union: Niskanen, Monnet or Thatcher?", Document de Travail Economie 2002-05, LATEC, Université de Bourgogne, Dijon; forthcoming in: J.-M. Josselin and A. Marciano (eds), From Economic to Legal Competition: New Perspectives on Law and Institutions in Europe, Cheltenham: Edward Elgar.

Salmon, Pierre (2003), "Assigning powers in the European Union in the light of yardstick competition among governments", Document de Travail Economie 2003-03, LATEC, Université de Bourgogne, Dijon; forthcoming in: Jahrbuch für Neue Politische Ökonomie, Band 21, "European governance".

Schneider, Friedrich (1996), "The design of a minimal European Federal Union: some ideas using the public choice approach", in: J. Casas Pardo and F. Schneider (eds), Current Issues in Public Choice, Cheltenham: Edward Elgar, pp. 203-220.

Tabellini, Guido (2002), "Principles of policymaking in the European Union: an economic perspective", paper prepared for the Munich Economic Summit, CESifo, Munich.

The Economist (2000), "Our constitution for Europe", 26 October.

Vaubel, Roland (1994), " The political economy of centralization and the European Community", Public Choice 81 (1-2), pp. 151-190.

Voigt, Stefan (1999), Explaining Constitutional Change: A Positive Economic Approach. Cheltenham: Edward Elgar.

Wallace, William (2000), "Collective governance: the EU political process," in: H. Wallace and W. Wallace (eds), Policy-Making in the European Union, 4th edition, Oxford and New York: Oxford University Press, chapter 19.

Winer, Stanley L. (2000), "On the reassignment of fiscal powers in a federal state", in: G. Galeotti, P. Salmon, and R. Wintrobe (eds), Competition and Structure: The Political Economy of Collective Decision-Making: Essays in Honor of Albert Breton, Cambridge and New York: Cambridge University 


\title{
CESifo Working Paper Series
}

\author{
(for full list see www.cesifo.de)
}

929 Paolo M. Panteghini and Guttorm Schjelderup, Competing for Foreign Direct Investments: A Real Options Approach, April 2003

930 Ansgar Belke, Rainer Fehn, and Neil Foster, Does Venture Capital Investment Spur Employment Growth?, April 2003

931 Assar Lindbeck, Sten Nyberg, and Jörgen W. Weibull, Social Norms and Welfare State Dynamics, April 2003

932 Myrna Wooders and Ben Zissimos, Hotelling Tax Competition, April 2003

933 Torben M. Andersen, From Excess to Shortage - Recent Developments in the Danish Labour Market, April 2003

934 Paolo M. Panteghini and Carlo Scarpa, Irreversible Investments and Regulatory Risk, April 2003

935 Henrik Jacobsen Kleven and Claus Thustrup Kreiner, The Marginal Cost of Public Funds in OECD Countries. Hours of Work Versus Labor Force Participation, April 2003

936 Klaus Adam, George W. Evans, and Seppo Honkapohja, Are Stationary Hyperinflation Paths Learnable?, April 2003

937 Ulrich Hange, Education Policy and Mobility: Some Basic Results, May 2003

938 Sören Blomquist and Vidar Christiansen, Is there a Case for Public Provision of Private Goods if Preferences are Heterogeneous? An Example with Day Care, May 2003

939 Hendrik Jürges, Kerstin Schneider, and Felix Büchel, The Effect of Central Exit Examinations on Student Achievement: Quasi-experimental Evidence from TIMSS Germany, May 2003

940 Samuel Bentolila and Juan F. Jimeno, Spanish Unemployment: The End of the Wild Ride?, May 2003

941 Thorsten Bayindir-Upmann and Anke Gerber, The Kalai-Smorodinsky Solution in Labor-Market Negotiations, May 2003

942 Ronnie Schöb, Workfare and Trade Unions: Labor Market Repercussions of Welfare Reform, May 2003

943 Marko Köthenbürger, Tax Competition in a Fiscal Union with Decentralized Leadership, May 2003 
944 Albert Banal-Estañol, Inés Macho-Stadler, and Jo Seldeslachts, Mergers, Investment Decisions and Internal Organisation, May 2003

945 Kaniska Dam and David Pérez-Castrillo, The Principal-Agent Matching Market, May 2003

946 Ronnie Schöb, The Double Dividend Hypothesis of Environmental Taxes: A Survey, May 2003

947 Erkki Koskela and Mikko Puhakka, Stabilizing Competitive Cycles with Distortionary Taxation, May 2003

948 Steffen Huck and Kai A. Konrad, Strategic Trade Policy and Merger Profitability, May 2003

949 Frederick van der Ploeg, Beyond the Dogma of the Fixed Book Price Agreement, May 2003

950 Thomas Eichner and Rüdiger Pethig, A Microfoundation of Predator-Prey Dynamics, May 2003

951 Burkhard Heer and Bernd Süssmuth, Cold Progression and its Effects on Income Distribution, May 2003

952 Yu-Fu Chen and Michael Funke, Labour Demand in Germany: An Assessment of NonWage Labour Costs, May 2003

953 Hans Gersbach and Hans Haller, Competitive Markets, Collective Decisions and Group Formation, May 2003

954 Armin Falk, Urs Fischbacher, and Simon Gächter, Living in Two Neighborhoods Social Interactions in the LAB, May 2003

955 Margarita Katsimi, Training, Job Security and Incentive Wages, May 2003

956 Clemens Fuest, Bernd Huber, and Jack Mintz, Capital Mobility and Tax Competition: A Survey, May 2003

957 Edward Castronova, The Price of 'Man' and 'Woman': A Hedonic Pricing Model of Avatar Attributes in a Synthetic World, June 2003

958 Laura Bottazzi and Marco Da Rin, Financing Entrepreneurial Firms in Europe: Facts, Issues, and Research Agenda, June 2003

959 Bruno S. Frey and Matthias Benz, Being Independent is a Great Thing: Subjective Evaluations of Self-Employment and Hierarchy, June 2003

960 Aaron Tornell and Frank Westermann, Credit Market Imperfections in Middle Income Countries, June 2003 
961 Hans-Werner Sinn and Wolfgang Ochel, Social Union, Convergence and Migration, June 2003

962 Michael P. Devereux, Measuring Taxes on Income from Capital, June 2003

963 Jakob de Haan, Jan-Egbert Sturm and Bjørn Volkerink, How to Measure the Tax Burden on Labour at the Macro-Level?, June 2003

964 Harry Grubert, The Tax Burden on Cross-Border Investment: Company Strategies and Country Responses, June 2003

965 Kirk A. Collins and James B. Davies, Measuring Effective Tax Rates on Human Capital: Methodology and an Application to Canada, June 2003

966 W. Steven Clark, Using Micro-Data to Assess Average Tax Rates, June 2003

967 Christopher Heady, The 'Taxing Wages' Approach to Measuring the Tax Burden on Labour, June 2003

968 Michael P. Devereux and Alexander Klemm, Measuring Taxes on Income from Capital: Evidence from the UK, June 2003

969 Bernhard Eckwert and Itzhak Zilcha, The Effect of Better Information on Income Inequality, June 2003

970 Hartmut Egger and Josef Falkinger, The Role of Public Infrastructure for Firm Location and International Outsourcing, June 2003

971 Dag Morten Dalen and Trond E. Olsen, Regulatory Competition and Multi-national Banking, June 2003

972 Matthias Wrede, Tax Deductibility of Commuting Expenses and Residential Land Use with more than one Center, June 2003

973 Alessandro Cigno and Annalisa Luporini, Scholarships or Student Loans? Subsidizing Higher Education in the Presence of Moral Hazard, June 2003

974 Chang Woon Nam, Andrea Gebauer and Rüdiger Parsche, Is the Completion of EU Single Market Hindered by VAT Evasion?, June 2003

975 Michael Braulke and Giacomo Corneo, Capital Taxation May Survive in Open Economies, July 2003

976 Assar Lindbeck, An Essay on Welfare State Dynamics, July 2003

977 Henrik Jordahl and Luca Micheletto, Optimal Utilitarian Taxation and Horizontal Equity, July 2003

978 Martin D. D. Evans and Richard K. Lyons, Are Different-Currency Assets Imperfect Substitutes?, July 2003 
979 Thorsten Bayindir-Upmann and Frank Stähler, Market Entry Regulation and International Competition, July 2003

980 Vivek Ghosal, Firm and Establishment Volatility: The Role of Sunk Costs, Profit Uncertainty and Technological Change, July 2003

981 Christopher A. Pissarides, Unemployment in Britain: A European Success Story, July 2003

982 Wolfgang Buchholz, Richard Cornes, and Wolfgang Peters, On the Frequency of Interior Cournot-Nash Equilibria in a Public Good Economy, July 2003

983 Syed M. Ahsan and Panagiotis Tsigaris, Choice of Tax Base Revisited: Cash Flow vs. Prepayment Approaches to Consumption Taxation, July 2003

984 Campbell Leith and Jim Malley, A Sectoral Analysis of Price-Setting Behavior in US Manufacturing Industries, July 2003

985 Hyun Park and Apostolis Philippopoulos, Choosing Club Membership under Tax Competition and Free Riding, July 2003

986 Federico Etro, Globalization and Political Geography, July 2003

987 Dan Ariely, Axel Ockenfels and Alvin E. Roth, An Experimental Analysis of Ending Rules in Internet Auctions, July 2003

988 Paola Conconi and Carlo Perroni, Self-Enforcing International Agreements and Domestic Policy Credibility, July 2003

989 Charles B. Blankart and Christian Kirchner, The Deadlock of the EU Budget: An Economic Analysis of Ways In and Ways Out, July 2003

990 M. Hasham Pesaran and Allan Timmermann, Small Sample Properties of Forecasts from Autoregressive Models under Structural Breaks, July 2003

991 Hyun Park, Apostolis Philippopoulos and Vangelis Vassilatos, On the Optimal Size of Public Sector under Rent-Seeking competition from State Coffers, July 2003

992 Axel Ockenfels and Alvin E. Roth, Late and Multiple Bidding in Second Price Internet Auctions: Theory and Evidence Concerning Different Rules for Ending an Auction, July 2003

993 Pierre Salmon, The Assignment of Powers in an Open-ended European Union, July 2003 